\title{
Article \\ The Impact of Resources on the Adaptability of State Forest Companies. Some Evidence from the State Forests National Forest Holding
}

\author{
Szymon Cyfert ${ }^{1, *(\mathbb{D}, \text { Wojciech Dyduch }}{ }^{2}$ (i) and Maciej Zastempowski ${ }^{3}$ (i) \\ 1 Institute of Management, Poznan University of Economics and Business, al. Niepodległosci 10, \\ 61-875 Poznan, Poland \\ 2 Faculty of Management, University of Economics in Katowice, 1 Maja 50, 40-287 Katowice, Poland; \\ dyduch@ue.katowice.pl \\ 3 Faculty of Economic Sciences and Management, Nicolaus Copernicus University in Torun, ul. Gagarina 13a, \\ 87-100 Torun, Poland; mz@umk.pl \\ * Correspondence: s.cyfert@ue.poznan.pl
}

Citation: Cyfert, S.; Dyduch, W.; Zastempowski, M. The Impact of Resources on the Adaptability of State Forest Companies. Some Evidence from the State Forests National Forest Holding. Forests 2022, 13,355. https://doi.org/10.3390/ f13020355

Academic Editors: Rosa Gallardo-Cobos, Pedro Sánchez-Zamora

and Pilar Fernandez-Rebollo

Received: 27 January 2022

Accepted: 18 February 2022

Published: 20 February 2022

Publisher's Note: MDPI stays neutral with regard to jurisdictional claims in published maps and institutional affiliations.

Copyright: (c) 2022 by the authors. Licensee MDPI, Basel, Switzerland. This article is an open access article distributed under the terms and conditions of the Creative Commons Attribution (CC BY) license (https:/ / creativecommons.org/licenses/by/ $4.0 /)$.

\begin{abstract}
Structural, economic, and climate changes human activity and the growing complexity of the business environment significantly affect the forestry sector, which faces the need to adapt to the dynamically changing environment by strategic development of appropriate resources and skills. In this paper, we attempted to take on the managerial lens of dynamic capabilities, i.e., the abilities to adapt to the changes in the business environment to analyze whether the forestry sector is able to strategically develop resources that influence adaptability. We have attempted to demonstrate how the resources of the forest enterprises affect the adaptability described by the dynamic capabilities construct. Bearing in mind the importance of State Forests, we collected data from 129 forest districts in Poland and applied the ordered logistic regression to identify models that show the impact of specific categories of resources onto the forestry sector adaptability, described by the construct of dynamic capabilities. The results suggest that the forest districts strategically investing in technological, as well as human resources and skills, have higher chances of maintaining and developing the ability to adapt to the constantly changing economic environment. At the same time, our findings show that financial, reputational, and marketable resources and skills have no impact on the adaptability of the State Forests National Forest Holding.
\end{abstract}

Keywords: resources; dynamic capabilities; adaptability; the state forests national forest holding

\section{Introduction}

\subsection{Adapting the Dynamic Capability Lens to Forest Management}

Today, forests worldwide face a multitude of stressors. First, climate changes impact environmental policies and forest management. Second, the forestlands experience increased threats from fires, insect and plant invasions, diseases, severe weather phenomena such as storms, floods, changing temperatures, or droughts. Third, the intensified economic and human activity, resulting in the increased demand for wood, influences logging practices, and tree harvesting. Due to these stressors, forest ecosystems change dynamically $[1,2]$. At the same time, the required sustainable forest management is a complex task, as on one hand forest management faces pressure resulting from the increased demand for wood, which requires intensified timber plantations [3]; while on the other hand, efforts need to assure sustainable development of the forest areas and to preserve the ecosystems for endangered species [4]. At the same time, due to selecting environmentally-friendly harvesting procedures, EU regulations, forest management costs increase [5]. As a result, forest management undergoes dynamic changes affecting its functioning to an extent larger than before. 
Facing changes and answering to them requires any organization to develop dynamic capabilities [6], i.e., the ability to adapt to the changing environment, to comply with complex management systems, and to treat challenges that appear as opportunities. Scholars researching dynamic capabilities posit that benefit from the challenges, substantial efforts need to be made on the organization's side. Namely, after sensing the challenge as an opportunity, the organization needs to secure necessary resources and shift them from current operations to processes and functions that will allow exploiting the opportunity effectively [7]. Smart and sustainable forest management based on such dynamic capabilities and sustainable resource management can improve forest resilience in the era of climate, environmental, and economic changes.

The main purpose of this paper is to demonstrate how the resources of the State Forests Holding affect the adaptability described by the dynamic capabilities construct. By adapting the lens of dynamic capabilities from the management discipline to forest management, we would like to show how forest enterprises manage resources, and how these resources influence the adaptability to the changing external environment and growing business complexity.

We carried out the research that would demonstrate the example of the State Forests Holding. As the majority of the forest lands in Poland under the State Forest Holding belong to the State Treasury, it will be interesting to see how the state-owned forestry resources affect the ability to adapt to external changes.

The Polish State Forests are over 90 years old, functioning despite many historical changes and turbulent economic times. It is the largest organization in the European Union managing forests which belong to the State Treasury of Poland. The organization of the enterprise is based on self-financing, as the State Forests do not benefit from the taxpayers' money. The forest units operate at the national, regional, and local levels employing almost 25 thousand people.

The dynamics of changes in the external environment encouraged us to carry out research concerning the impact of resource management on the ability of State Forests to adapt to the changing environment. Through assessing how resources impact forest organizations in a changing environment, we identify the elements that are significant for the organization's adaptability.

As we take on the lenses of resource-based perspective rooted in the management discipline, in the first part of the paper, we attempt to show the resource-based view in the context of the forestry sector. In the second part of the paper, we discuss the construction of an organization's adaptability to environmental changes as the dynamic capability. As a result, a conceptual model illustrating the dimensions of an organization's adaptability influenced by certain groups of resources is identified.

In the next section, we present the research methodology. We describe the method of collecting data, demonstrate the key variables assessed, and indicate the statistical methods used for further data analysis. The third section presents the results of identifying the five stages of shaping dynamic capabilities ((1) Looking for opportunities, (2) Learning, (3) Coordinating, (4) Configuring and reconfiguring, (5) Adapting to changes). The final part of the paper covers the discussion of results, presents conclusions, indicates the limitations of the research, and presents the potential future research directions.

\subsection{Resource-Based View Approach in the Context of the Forestry Sector}

Although forest resources are usually equated with wood and non-wood resources [8-12], the functioning of organizations in the forestry sector would not be possible without the availability of other categories of resources. When describing the transition of the Finnish forest-based companies to the circular bioeconomy, the emphasis is made on intangible resources (human, social and organizational capital), developing organizational culture, and future-oriented strategic thinking [13]. The significance of such resources and processes as coordination, human capital, communication with stakeholders, and financial resources has been identified in the Indonesian agro-forest sector [14]. Eggers et al. note 
the growing role of intangible resources in the process of strategies selection by individual forest owners in Sweden [15]. Similarly, the research of Neykov et al. suggests that the need for developing human resources is critical when implementing innovations based on emerging technologies in the forestry sector [16].

Considering The State Forests Holding as a specific form of organization [17], we adopted the Resource-Based View, a well-known approach rooted in the management discipline [18-20] which assumes that every organization is a bundle of resources, processes, routines, and capabilities that create value [6,21]. To explain the performance differences among organizations, the Resource-Based View assumes that the sources of competitive advantage are based on both tangible and intangible assets, which are used by the organization to create and implement competitive strategies [22]. Such perception of the organization's nature means that the strategic goal of every company-that wants to remain competitive and well-performing - should be to develop and strategically invest in a combination of valuable and scarce resources that cannot be imitated, replaced, or purchased by competitors [23].

Referring to the scholarly discussion [24-28] we distinguished seven categories of resources [29]: (1) technological resources and skills-related to the development of techniques and mechanisms of resource processing, allowing to build added value for stakeholders; (2) financial resources and skills_-related to assuring the level of financing in the long term, shaping the capital structure, proper cost management, as well as self-financing; (3) human resources and skills_-related to employee recruiting and onboarding, as well as organizational learning that ensures a dynamic response to the changes taking place; (4) reputational resources and skills-related to shaping brand recognition and building trust, which stimulates the level of stakeholder engagement; (5) structural resources and skills-related to shaping the internal architecture of the organization and designing exchange processes with the environment; (6) institutional resources and skills-related to managing relations with stakeholders; (7) market resources and skills—related to demandbased activity diversification and innovativeness.

\subsection{The Importance of Adaptability during Dynamic Environmental Changes}

The forest sector has long been identified as a mature industry [30]. The 90-year history of the State Forests in Poland seems to prove this argument. However, structural changes [31], the increasing complexity of the business environment [32], and many different driving forces affect significant changes in the forestry sector to date [33]. Climate and weather changes, natural threats, intense human activity [1], economic pressure resulting from the increased demand for wood [3], coupled with EU regulations and activities assuring forest sustainable management [4], increasing costs of forest management [5] results in forestry sector undergoing dynamic changes that affect its functioning to an extent larger than before. Indeed, Senko and Pykäläinen indicate that the forestry sector is now much more dynamic and less predictable than in the past [34] while Näyhä \& Pesonen posit that in some respects the forest industry is facing challenges that have already been observed in other sectors [33], forcing the need to implement fundamental changes and compete in global markets [35].

Dynamic changes coupled with a steady increase of the environment's complexity of organizations from the forest sector [13] provoke the need for analyzing the activities undertaken by the forest organizations through the lens of the dynamic capabilities construct, which can shed light on the significance to maintain and renew advantages in the constantly changing environment [36-38]. Dynamic capabilities [6] - the abilities to adapt to the changing environment and complex management systems by sensing and exploiting opportunities require organizations to shift the necessary resources from to-date operations to processes, functions, and places that will allow the organization to effectively exploit the opportunity and build the advantage [7].

Teece, Pisano, and Shuen (2009) posit that dynamic capabilities represent the organization's potential to integrate, create and reconfigure internal and external competencies, 
which ensures compliance with constantly changing environmental conditions [28]. In turn, Eisenhardt and Martin treat dynamic abilities as intra-organizational processes such as integrating, reconfiguring, and acquiring or managing resources that allow to comply with changes in the market or to generate these changes [25]. It is worth noting, however, that while the original assumptions indicated that the construct of dynamic capabilities can describe the behaviors of organizations operating in a highly dynamic and turbulent environment [28], it is now argued that developing dynamic capabilities in an environment with a relatively low level of stability is also feasible [36].

One of the important features of dynamic capabilities is organizational change management [25,37,39-42]. Taking this assumption into consideration, our research procedure posits that shaping dynamic capabilities includes five stages [29]: (1) searching for opportunities related to analyzing trends and environmental phenomena, creating new ideas and identifying the need for changes; (2) learning, related to acquiring knowledge, transferring, allocating and storing knowledge within an organization, managing intellectual property, encouraging employees to innovate and experiment; (3) coordinating activities related to creating a vision, integrating supply chain processes, managing strategic alliances, building employee involvement, creating consistent decision-making rules, integrating and coordinating business processes; (4) configuring and reconfiguring, related to the creation, acquisition, and integration of resources and skills; creating innovation, divesting unnecessary resources and skills, implementing new technologies; (5) organization adapting, related to the transformation of the business model, management of the boundaries of the organization, ensuring a dynamic process of strategic management, improvement of the organization, adaptation and implementation of the best management practices, ensuring the flexibility of the organizational structure, managing the identity of the organization. The resources that shape dynamic capabilities are presented in Figure 1.

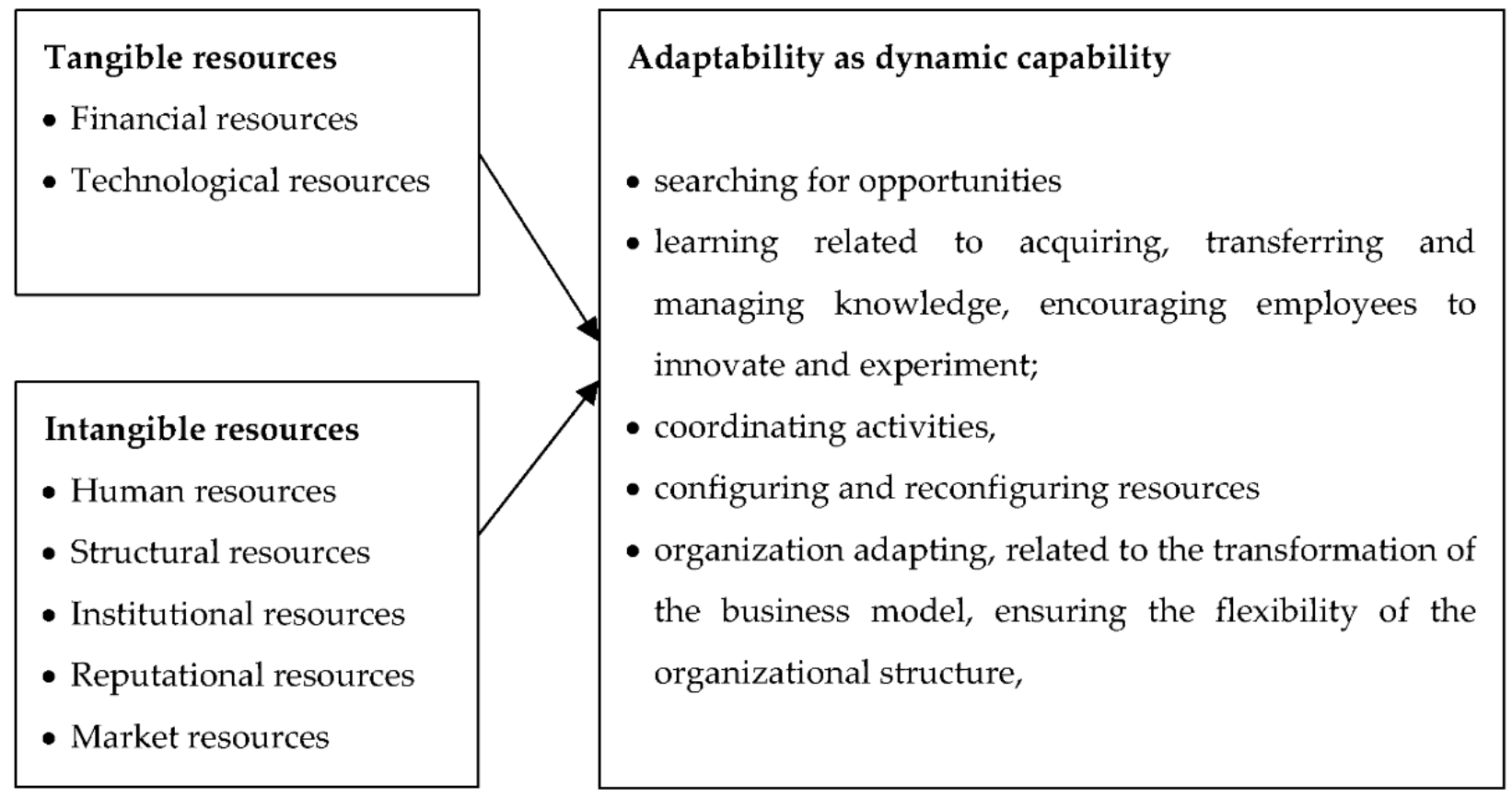

Figure 1. The impact of resources on forest enterprise dynamic capabilities.

\subsection{Some Facts about the State Forests Holding}

In 2019, forests in Poland covered 30.9\% (9.3 million ha) of land area, which means an increase of $9 \%$ compared to 1990 [43]. The ownership structure is dominated by state ownership-slightly over $80 \%$ (7.5 million ha) of forests area are owned by the State Treasury of Poland and 19.3\% (1.8 million ha) are owned by private owners [43]. Supervision over forest management in private forests is exercised by the starost (local government 
officer in Polish administration), however, according to the law, a private owner may prohibit access to the forest, although this is not a binding practice. Over $70 \%$ of starosties entrust the State Forests Holding with supervision over forest management in private forests. The entity responsible for permanently sustainable forest management in Poland is The State Forests Holding, which is an organizational unit without legal personality [44]. The management process at SFH is carried out on three levels [45]:

- General Director level appointed by the Ministry of the Environment and managing Polish State Forests. Their office is the Directorate-General of the State Forests, and the director's advisory body is the Council of the State Forests.

- $\quad$ Regional directorates level (17), whose tasks include, among all, the supervision over subordinate units and coordination of activities in their territory.

- Forest districts level (429), engaged in forest management based on a forest management plan. The head of the unit is responsible for the condition of the forest in its area. Forest divisions are divided into forest units.

The "Strategy of the State Forests Holding for the years 2014-2030" [46], introduced in December 2013, defines the mission, vision, and strategic goals relating to seven areas: (1) Values provided to stakeholders; (2) Ensuring the sustainability of forests (forests as the most important element of the environment); (3) Ensuring the availability of forests to society (forests as a social good); (4) Ensuring a significant contribution of the State Forests to the development of the economy (forestry as an important sector of the economy and a creator of the development of rural areas); (5) Building competence in a modern, wellmanaged and efficient organization; (6) Developing human resources and competences as well as motivating to implement the strategy; (7) Ensuring the ability to self-finance.

\subsection{Goal and Structure}

The main purpose of the article is to demonstrate how the State Forests National Forest Holding resources affect the adaptability described by the dynamic capabilities construct. The paper is structured as follows: in Section 2, we present the materials and methods. We describe the method of obtaining materials, variables, and statistic methods. Section 3 presents the results of calculations and discussion for the five logit regression models for stages of shaping dynamic abilities ((1) Looking for opportunities, (2) Learning, (3) Coordination, (4) Configuration and reconfiguration, (5) Adaptation). The last section contains conclusions, points to the limitations of the research procedure and presents the research directions that, in our opinion, need to be developed in the future.

\section{Research Methodology}

\subsection{Sample and Data Collection}

To demonstrate how the resources of the State Forests Holding affect the adaptability of the whole organization, we decided to carry out a survey and analyze the collected data with quantitative methods. Based on the scholarly discussion on resource-based view, dynamic capabilities, as well as the forestry sector characteristics, a standardized questionnaire was developed. It consisted of three groups of statements that aimed to assess: (1) the level of achieving strategic goals by State Forests, (2) the importance of dynamic capabilities for achieving the strategic goals, (3) the importance of critical resources and skills for implementing the strategic goals, adopted in the State Forests Holding strategy. The research results presented in this paper concentrate on the third part of the questionnaire, as they assess the importance of critical resources and skills for implementing the strategic goals defined in the State Forests Holding strategy.

The questionnaire was sent to the heads of 430 local forest districts in Poland. The forms were filled in with the CAWI technique (Computer-Assisted Web Interview). One hundred and twelve correctly completed questionnaires were obtained till February 2019 (the general results of this survey are presented in [29]), and additional 17 questionnaires were obtained till May 2019, which gave a total of 129 completed questionnaires. 


\subsection{Variables}

Table 1 presents the description, labels, types, and basic descriptive statistics of all the analyzed variables. Both explanatory and explained variables were measured using a five-point ordinal scale, where 1 -meant no impact, while 5-meant very big impact.

Table 1. Description of variables used in the research.

\begin{tabular}{|c|c|c|c|c|c|c|c|c|c|c|}
\hline Description & Label & Type & Mean & S.E. & $\mathbf{M}$ & D & S.D. & $\mathrm{SD}^{2}$ & Min. & $\operatorname{Max} *$ \\
\hline \multicolumn{11}{|l|}{ Explanatory variables } \\
\hline Technological resources and skills & $\mathrm{x}_{1}$ & Ordinal (1-5) & 3.783 & 0.075 & 4 & 4 & 0.857 & 0.734 & 2.0 & 5.0 \\
\hline Financial resources and skills & $x_{2}$ & Ordinal (1-5) & 4.062 & 0.083 & 4 & 4 & 0.942 & 0.887 & 2.0 & 5.0 \\
\hline Human resources and skills & $x_{3}$ & Ordinal (1-5) & 4.279 & 0.084 & 5 & 5 & 0.952 & 0.906 & 2.0 & 5.0 \\
\hline Reputational resources and skills & $x_{4}$ & Ordinal $(1-5)$ & 3.922 & 0.081 & 4 & 4 & 0.924 & 0.853 & 2.0 & 5.0 \\
\hline Structural resources and skills & $x_{5}$ & Ordinal (1-5) & 3.690 & 0.078 & 4 & 4 & 0.882 & 0.778 & 1.0 & 5.0 \\
\hline Institutional resources and skills & $x_{6}$ & Ordinal $(1-5)$ & 3.721 & 0.073 & 4 & 4 & 0.829 & 0.687 & 1.0 & 5.0 \\
\hline Marketable resources and skills & $x_{7}$ & Ordinal (1-5) & 3.806 & 0.079 & 4 & 4 & 0.893 & 0.798 & 2.0 & 5.0 \\
\hline \multicolumn{11}{|l|}{ Explained (dependent) variables } \\
\hline Looking for opportunities & $\mathrm{y}_{1}$ & Ordinal (1-5) & 3.860 & 0.078 & 4 & 4 & 0.882 & 0.777 & 1.0 & 5.0 \\
\hline Learning & $\mathrm{y}_{2}$ & Ordinal $(1-5)$ & 3.767 & 0.086 & 4 & 4 & 0.972 & 0.945 & 1.0 & 5.0 \\
\hline Coordination & $\mathrm{y}_{3}$ & Ordinal (1-5) & 3.713 & 0.083 & 4 & 4 & 0.943 & 0.890 & 1.0 & 5.0 \\
\hline Configuration and reconfiguration & $\mathrm{y}_{4}$ & Ordinal (1-5) & 3.655 & 0.076 & 4 & 4 & 0.859 & 0.737 & 1.5 & 5.0 \\
\hline Adaptation & $\mathrm{y}_{5}$ & Ordinal (1-5) & 3.713 & 0.089 & 4 & 4 & 1.009 & 1.019 & 1.0 & 5.0 \\
\hline
\end{tabular}

* Note: S.E.-Standard Error; M-Median; D.-Dominant; S.D.—Standard Deviation; SD $^{2}$-Variance; Min Max.-minimal and maximal value.

\subsection{Methods}

In order to analyze the collected data, we used quantitative statistical methods. First, to analyze the internal consistency of applied scales, we used the Alpha Cronbach coefficient. According to Hair et al., its minimum acceptable value is 0.7 [47].

Second, to evaluate the sample adequacy for all variables, the Kaiser-Meyer-Olkin (KMO) and Bartlett sphericity tests were analyzed. The KMO is a test conducted to examine the strength of the partial correlation between variables. The test measures sampling adequacy for each variable in the model and for the complete model. KMO values closer to 1.0 are considered ideal, while values less than 0.5 are considered unacceptable [48].

In turn, Bartlett's test of sphericity was used to test the null hypothesis that the correlation matrix is an identity matrix. An identity correlation matrix means the variables are unrelated and not ideal for the factor analysis. A significant statistical test (usually less than 0.05 ) shows that the correlation matrix is indeed not an identity matrix (rejection of the null hypothesis) [49].

Third, to analyze the effect of the explanatory variables on the explained (dependent) variables, we used the ordered logistic regression model, which is an extension of the binary model specification to more thresholds. Wilkelman and Boes indicate that models for ordered dependent variables are usually motivated by an underlying continuous but latent process $y_{i}^{*}$ given by:

$$
y_{i}^{*}=x_{i}^{\prime} \beta+u_{i} \quad i=1, \ldots, n
$$

with the deterministic component $x_{i}^{\prime} \beta$ (the linear index of regressors), and the random terms $u_{i}$, which are assumed to be independently and identically distributed with the distribution function $F(u)$ with a mean of zero and constant variance [50].

For the interpretation of obtained results, we used also the odds ratios (OR). If we mark the chance as:

$$
\frac{p_{i}}{1-p_{i}}=\exp \left(x_{i}^{\prime} \beta\right)=\exp \left(\beta_{0}+\beta_{1} X_{1 i}+\beta_{2} X_{2 i}+\ldots+\beta_{k} X_{k i}\right)=\Omega\left(x_{i}\right)
$$


is the odds ratios with the variable $X_{m i}$ increased by a unit and the odds without this increase equal:

$$
\frac{\Omega\left(x_{i}^{m}, X_{m i}+1\right)}{\Omega\left(x_{i}^{m}, X_{m i}\right)}=\exp \left(\beta_{m}\right)
$$

where $x_{i}^{m}$ is the vector $x_{i}$ without the variable $X_{m i}$. Formula (3) shows that an increase in the value of $X_{m i}$ by one unit is related, ceteris paribus, with an $\exp \left(\beta_{m}\right)$-fold change in the odds ratio. In the case of $\exp \left(\beta_{m}\right)>1$ we have an increase, and in the case of $\exp \left(\beta_{m}\right)<1$ we have a decrease in the odds ratio.

To estimate all of the models, we used the maximum likelihood estimation method and STATA.16.1 software.

\section{Results and Discussion}

Below, we present the results of the quantitative analyses regarding the questionnaire reliability and the influence of resource management on forest units' adaptability.

First, it is important to assess the reliability of our questionnaire. The analysis of the internal consistency of the scales shows the Alpha Cronbach coefficient as acceptable (Table 2). The KMO measures were 0.856 and 0.860, and the Bartlett sphericity test (ChSquare $=475.947$ and 462.199) at a significance level of 0.000 confirmed the reliability of the research tool. These values are acceptable for this type of analysis (de Vaus 2002).

Table 2. Measurement properties indicating the questionnaire reliability.

\begin{tabular}{cccc}
\hline Variables & Cronbach's Alpha Test & Kaiser-Meyer-Olkin Test & Bartlett's Test \\
\hline Explanatory & 0.888 & 0.856 & $475.947 *$ \\
Explained & 0.918 & 0.860 & $462.199 *$ \\
$* p<0.000$. &
\end{tabular}

The results of the ordered logistic regression estimates are shown in Table 3, while the values of the odds ratios are in Table 4.

The plausibility tests indicate the significance of all the identified models (labeled $\mathrm{y}_{1}-$ $\mathrm{y}_{5}$ ). The likelihood-ratio tests used to verify the null hypothesis indicate that a model with only $\mathrm{k}$ thresholds is as good as the estimated model $(53.11,67.07,82.19,99.49$, and 97.24, respectively). At seven degrees of freedom, the empirical significance level is 0.0000 , so we can reject the null hypothesis in favor of the alternative hypothesis-that the estimated models are better than those that only account for thresholds.

The analysis results suggest that certain resources have a positive influence on the adaptability of the State Forests Holding, as described by the construct of dynamic capabilities. We can further interpret the models based on the odds ratios. In case of the ordered logistic models, the regression coefficient direction (negative or positive) matters. The positive value means that the probability of adaptability increase will be higher in forest units that strategically invest in a given resource, contrary to these firms that do not. In turn, the negative coefficient value indicates that the probability of decreasing adaptability will be higher in these forest units that adopt a given mechanism (described by the independent variable). What matters are the odds ratios (presented in Table 4) demonstrating the level of a given probability. When regression coefficient is negative, odds ratios take values below 1; when positive, odds ratios are higher than 1. 
Table 3. Ordered logistic regression indicating impact of resources (x) onto adaptability (y)

\begin{tabular}{|c|c|c|c|c|c|c|c|c|c|c|}
\hline \multirow[t]{2}{*}{ Variables } & \multicolumn{2}{|c|}{$\begin{array}{c}y_{1} \\
\text { Looking for } \\
\text { Opportunities }\end{array}$} & \multicolumn{2}{|c|}{$\stackrel{\mathrm{y}_{2}}{\text { Organizational Learning }}$} & \multicolumn{2}{|c|}{$\begin{array}{c}\mathrm{y}_{3} \\
\text { Coordination }\end{array}$} & \multicolumn{2}{|c|}{$\begin{array}{c}\mathrm{y}_{4} \\
\text { Configuration \& } \\
\text { Reconfiguration }\end{array}$} & \multicolumn{2}{|c|}{$\begin{array}{c}\mathrm{y}_{5} \\
\text { Adaptation }\end{array}$} \\
\hline & Coef. & S.E. & Coef. & S.E. & Coef. & S.E. & Coef. & S.E. & Coef. & S.E. \\
\hline $\mathrm{x}_{1}$ : Technological resources and skills & 0.530 * & 0.274 & $0.765^{* * *}$ & 0.272 & $0.733^{* * *}$ & 0.256 & $1.254^{* * *}$ & 0.277 & 0.413 & 0.268 \\
\hline $\mathrm{x}_{2}$ : Financial resources and skills & 0.436 & 0.305 & 0.202 & 0.288 & 0.434 & 0.280 & $0.520^{*}$ & 0.284 & 0.479 & 0.298 \\
\hline $\mathrm{x}_{3}:$ Human resources and skills & 0.441 & 0.269 & $0.996^{* * *}$ & 0.281 & $0.825^{* * *}$ & 0.240 & $0.695^{* * *}$ & 0.250 & $1.002^{* * *}$ & 0.276 \\
\hline $\mathrm{x}_{4}$ : Reputational resources and skills & 0.232 & 0.299 & -0.376 & 0.289 & -0.092 & 0.269 & -0.286 & 0.285 & 0.116 & 0.291 \\
\hline $\mathrm{x}_{5}$ : Structural resources and skills & 0.171 & 0.305 & 0.106 & 0.327 & $0.491 *$ & 0.289 & 0.359 & 0.293 & $0.899^{* * *}$ & 0.332 \\
\hline $\mathrm{x}_{7}$ : Marketable resources and skills & -0.157 & 0.305 & -0.123 & 0.285 & -0.110 & 0.282 & -0.422 & 0.297 & -0.171 & 0.295 \\
\hline /cut1 & 1.551 & 1.345 & 2.211 & 1.352 & 3.164 & 1.367 & 3.837 & 1.377 & 4.212 & 1.424 \\
\hline /cut2 & 4.232 & 1.024 & 6.124 & 1.152 & 4.326 & 1.101 & 7.061 & 1.111 & 8.965 & 1.375 \\
\hline /cut3 & 6.480 & 1.145 & 7.735 & 1.240 & 6.238 & 1.063 & 7.779 & 1.145 & 10.955 & 1.521 \\
\hline /cut4 & 9.211 & 1.269 & 10.516 & 1.373 & 7.620 & 1.160 & 10.087 & 1.332 & 13.890 & 1.681 \\
\hline /cut5 & & & & & 8.901 & 1.255 & 11.039 & 1.379 & & \\
\hline /cut6 & & & & & 9.499 & 1.286 & 13.380 & 1.491 & & \\
\hline /cut7 & & & & & 11.534 & 1.371 & 13.979 & 1.517 & & \\
\hline Log likelihood & -133.680 & & -133.901 & & -199.383 & & -178.012 & & -123.191 & \\
\hline LR chi2 (7) & 53.11 & & 67.07 & & 82.19 & & 99.49 & & 97.24 & \\
\hline Prob > chi2 & 0.0000 & & 0.0000 & & 0.0000 & & 0.0000 & & 0.0000 & \\
\hline Pseudo $R^{2}$ & 0.1657 & & 0.2003 & & 0.1709 & & 0.2184 & & 0.2830 & \\
\hline
\end{tabular}


Table 4. Odds ratio for $\mathrm{y}_{1}, \mathrm{y}_{2}, \mathrm{y}_{3}, \mathrm{y}_{4}, \mathrm{y}_{5}$ models.

\begin{tabular}{cccccc}
\hline Variables & $\mathbf{y}_{\mathbf{1}}$ & $\mathbf{y}_{\mathbf{2}}$ & $\mathbf{y}_{\mathbf{3}}$ & $\mathbf{y}_{\mathbf{4}}$ & $\mathrm{y}_{\mathbf{5}}$ \\
\hline $\mathrm{x}_{1}$ : Technological resources and skills & $1.698^{*}$ & $2.149^{* * *}$ & $2.082^{* * *}$ & $3.505^{* * *}$ & 1.511 \\
$\mathrm{x}_{2}$ : Financial resources and skills & 1.546 & 1.224 & 1.543 & 1.683 & 1.614 \\
$\mathrm{x}_{3}$ : Human resources and skills & 1.554 & $2.708^{* * *}$ & $2.282^{* * *}$ & $2.004^{* * *}$ & $2.723^{* * *}$ \\
$\mathrm{x}_{4}$ : Reputational resources and skills & 1.261 & 0.686 & 0.912 & 0.751 & 1.123 \\
$\mathrm{x}_{5}$ : Structural resources and skills & 1.187 & 1.112 & $1.634^{*}$ & 1.432 & $2.457^{* * *}$ \\
$\mathrm{x}_{6}$ : Institutional resources and skills & 1.312 & $1.862^{*}$ & 1.262 & $2.045^{* *}$ & 1.273 \\
$\mathrm{x}_{7}$ : Marketable resources and skills & 0.854 & 0.884 & 0.895 & 0.656 & 0.843 \\
\hline
\end{tabular}

${ }^{*} p<0.1{ }^{* *} p<0.05,{ }^{* * *} p<0.01$.

We can conclude, that in case of looking for opportunities $\left(\mathrm{y}_{1}\right)$, bearing in mind the ceteris paribus assumption - that all the other variables in the model remain unchanged, the chance for the increase in the importance of looking for opportunities is greater in the group of local forest districts in Poland which rate higher the importance of:

- technological resources and skills-by $69.8 \%$.

In the case of learning $\left(\mathrm{y}_{2}\right)$ - ceteris paribus - the chance for the increase in the importance of learning is greater in the group of local forest districts in Poland which rate higher the importance of:

- technological resources and skills-by $114.9 \%$,

- human resources and skills-by $170.8 \%$,

- institutional resources and skills-by $86.2 \%$.

In the case of coordination $\left(\mathrm{y}_{3}\right)$-ceteris paribus - the chance for the increase in the importance of coordination is greater in the group of local forest districts in Poland, which rate higher the importance of:

- technological resources and skills-by $108.2 \%$,

- human resources and skills-by $128.2 \%$,

- $\quad$ structural resources and skills-by $63.4 \%$.

In the case of configuration and reconfiguration $\left(\mathrm{y}_{4}\right)$-ceteris paribus-the chance for the increase in the importance of configuration and reconfiguration is greater in the group of local forest districts in Poland, which rate higher the importance of:

- technological resources and skills-by $250.5 \%$,

- human resources and skills-by $100.4 \%$,

- institutional resources and skills-by $104.5 \%$.

And at least, in the case of adaptation $\left(\mathrm{y}_{5}\right)$-ceteris paribus - the chance for the increase in the importance of adaptation is greater in the group of local forest districts in Poland, which rate higher the importance of:

- human resources and skills-by $172.3 \%$,

- $\quad$ structural resources and skills-by $145.7 \%$.

Although we observed a positive impact of resources on the adaptability of the State Forests Holding in four $\left(\mathrm{x}_{1}, \mathrm{x}_{3}, \mathrm{x}_{5}\right.$, and $\left.\mathrm{x}_{6}\right)$ out of the seven analyzed categories of resources (see Figure 1), the obtained results allow us to argue that the chances of maintaining and developing the ability to adapt to the constantly changing environment are particularly high in the group of forest districts developing:

- technological resources and skills $\left(\mathrm{x}_{1}\right)$

- human resources and skills $\left(\mathrm{x}_{3}\right)$.

Our results in this area are in line with the findings of Näyhä, emphasizing the importance of human resources in the transition of Finnish forest companies to a circular bioeconomy [13], Nurrochmat et al., pointing to the importance of human capital in the Indonesian agricultural-forestry sector [14] and Neykov et al. emphasizing the importance of implementing innovation in emerging technologies in the forestry sector [16]. 
It is worth noting that the results suggest that technological resources and skills do not affect adaptability, while human resources and skills do not affect the ability for opportunity sensing. While the lack of impact of technological resources and skills on adaptability can be explained by the "soft" (not requiring a strong support of technology) nature of activities related to change management [51], the previous research [52-54] suggested the impact of human resources and skills on looking for, sensing and identifying opportunities. Our research results suggest that there is no link between human resources and skills with looking for, and sensing opportunities is puzzling. Therefore, in future research, it would be worthwhile to deepen the analysis of the relationship between the human resources and skills and the ability of opportunity sensing, identifying, and exploiting, especially in the context of the ability to analyze the environment aimed at creating new customer needs, anticipating the actions of competitors, as well as the ability to create new ideas with regard to the awareness of changes in the environment.

The structure outlined in Figure 2 suggests that the process of maintaining and developing the dynamic capability based on adapting to the changing business environment requires state forest enterprises to develop mostly technological, human, structural and institutional resources, and skills. On the other hand, financial, reputational, and marketable resources and skills have no impact on the state forest's adaptability.

\begin{tabular}{|c|c|c|c|c|}
\hline \multicolumn{5}{|l|}{$300 \%$} \\
\hline \multicolumn{5}{|l|}{ 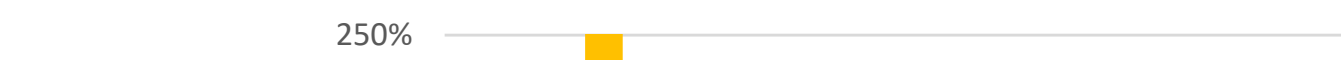 } \\
\hline \multirow{2}{*}{\multicolumn{5}{|c|}{$150 \%$}} \\
\hline & & & & \\
\hline $100 \%$ & & & & \\
\hline $50 \%$ & & & & \\
\hline $0 \%$ & $x 1$ & $x 3$ & $\times 5$ & $x 6$ \\
\hline y1 - looking for opportunities & $70 \%$ & & & \\
\hline y2 - learning & $115 \%$ & $171 \%$ & & $86 \%$ \\
\hline y3 - coordination & $108 \%$ & $128 \%$ & $63 \%$ & \\
\hline $\begin{array}{l}\text { y4 - configuration and } \\
\text { reconfiguration }\end{array}$ & $251 \%$ & $100 \%$ & $43 \%$ & $105 \%$ \\
\hline y5 - adaptation & & $172 \%$ & $146 \%$ & \\
\hline
\end{tabular}

Figure 2. Odds ratio for statistically significant variables in all logistic regression models.

Our study indicated the lack of impact of financial resources and skills onto the dynamic capabilities of the State Forests' Holding. This can be explained by the nature of State Forests financing (self-financing), but it can also be the result of respondent selection. We examined the perception of resources and dynamic capabilities at the lower level of management (forest districts), which, although have a certain degree of financial independence, are limited to key financial decisions reserved for the higher levels (the regional directorates and the CEO). Thus, the low assessment of the possibilities of forest districts' influence on financial resources and skills could translate into the lack of perceiving the impact of strategic support of financial resources and skills on the possibility of dynamic adaptation to changes in the environment. Therefore, we believe that future research could be designed to analyze the perceived impact of financial resources and skills at the higher levels of management of the state forests.

When attempting to explain the lack of impact of reputational resources and skills on dynamic capabilities of the state forest enterprise, it can be noticed that the high, wellestablished reputation of the State Forests Holding could paradoxically cause its influence on dynamic abilities to be ignored. The respondents, although they were aware of the 
well-established reputation of the company, most likely assumed that it would be difficult to increase it, therefore they looked for opportunities to improve other variables whose current assessment was lower than the expected potential.

Our findings suggest a low level of importance of marketable resources and skills, which can be explained by the monopolistic position of the Polish State Forests, thus ignoring the importance of developing the elements necessary for the increased competitiveness. However, observing the dynamic changes taking place [31-35], it seems that marketable resources and skills should not be ignored, and their impact on dynamic skills could prove greater in the nearest future.

\section{Conclusions}

Forest organizations operate today under the influence of multiple external stressors. Climate changes, increased natural threats, intensified economic and human activity, affect complex forest management. A dynamically changing environment requires today's organizations to react to changes, and to treat the challenges that appear as opportunities that can be used to build competitive advantage.

We have attempted to demonstrate the construct of dynamic capabilities-the construct rooted in strategic management, understood as the organization's ability to adapt to the changing environment-and introduce it to the area of forest management.

The dynamic capability construct assumes that the challenges appearing in the complex, dynamic, and often hostile environment can be promptly recognized as opportunities, which an organization can benefit from. However, in order to benefit from opportunities, organizations need to quickly shift and assure resources and take action.

In our study, we have attempted to assess which resources of the State Forests Holding positively influence their adaptability to the changing environment, which is seen as the foundation of the dynamic capabilities. The research intent focused on the forest districts, where operational activities (including assuring resources and shifting them for opportunity exploitation) are undertaken by the local unit managers.

Our studies provide some evidence for the significance of certain groups of resources on the adaptability of the State Forests Holding to the changing business environment.

Our study revealed that different categories of resources and skills are important at various stages of the process of shaping dynamic capabilities. At the stage of (1) searching for opportunities, technological resources and skills are significant; (2) in organizational learning human resources and skills, technological, and institutional resources and skills play a major role; (3) for coordination human, technological and structural resources and skills are significant; (4) at the stage of configuration and reconfiguration technological, institutional and human resources and skills are required; (5) for organization's adaptation human resources are crucial.

Our findings allow us to draw the conclusion that the process of maintaining and developing the dynamic capabilities based on adapting to the changing business environment requires state forest enterprises to seek for, develop and maintain mostly technological, human, structural and institutional resources, and skills, while the other three categories of resources (financial, reputational, and marketable resources and skills) have no impact on the state forests adaptability.

The results of our research have implications for theory as well as managerial practice. First, we have demonstrated the impact of specific categories of resources on dynamic abilities. Second, our findings highlight the significance of strategic support and a need to invest in certain groups of resources. The results indicating that technological, human, structural, and institutional resources are related to dynamic capabilities reflected in adapting the organization to changes in the environment should encourage the State Forests Holding to acquire, develop and maintain appropriate resources and skills over time.

We are aware that our research has certain limitations. First, we have only reached 129 forest districts out of 429 existing, which makes it limited to draw general conclusions. In future research, it would be worthwhile to increase the sample, deepening at the same 
time the issue of reputational and financial resources' impact on dynamic capabilities. What is more, the disputable relationship between human resources and skills and opportunity seeking, sensing, and exploiting could be further explored. Second, our research was carried out at the forest district level of the State Forests Holding. In future research, it would be worthwhile to survey all managerial levels, which would allow us to assess the convergence of perceptions of change processes throughout the whole (the State Forests Holding) organization. Third, the survey used subjective data (managerial perceptions), which may have had an impact on the results obtained. We believe that it would be worth identifying a research model with moderating or mediating variables, more contextual and control variables, in order to formulate general conclusions about the effectiveness of the State Forests Holding activities. Fourth, one of the results of developing the dynamic capabilities and exploiting the opportunities by the organization is innovating. The need for innovative activity is visible in the forestry sector facing environmental regulations and the pressure to select cost-intensive environmental-friendly solutions $[55,56]$. We see this stream of future research as promising and relevant to the forestry sector.

Author Contributions: Conceptualization, S.C., W.D. and M.Z.; Methodology, S.C. and W.D.; Software, M.Z.; Validation, M.Z. and W.D.; Formal Analysis, W.D.; Investigation, M.Z. and S.C.; Resources, S.C.; Data Curation, M.Z.; Writing-Original Draft Preparation, S.C. and M.Z.; Writing-Review \& Editing, W.D.; Visualization, M.Z.; Supervision, S.C.; Project Administration, S.C. All authors have read and agreed to the published version of the manuscript.

Funding: This research received no external funding.

Institutional Review Board Statement: Not applicable.

Informed Consent Statement: Not applicable.

Data Availability Statement: The data presented in this study are available on request from the corresponding author.

Conflicts of Interest: The authors declare no conflict of interest.

\section{References}

1. Sun, J.; Feng, L.; Wang, T.; Tian, X.; He, X.; Xia, H.; Wang, W.; Barton, A.M. Predicting the Potential Habitat of Three Endangered Species of Carpinus Genus under Climate Change and Human Activity. Forests 2021, 12, 1216. [CrossRef]

2. Thakur, T.K.; Patel, D.K.; Thakur, A.; Kumar, A.; Bijalwan, A.; Bhat, J.A.; Kumar, A.; Dobriyal, M.J.; Kumar, M.; Kumar, A. Biomass Production Assessment in a Protected Area of Dry Tropical forest Ecosystem of India: A Field to Satellite Observation Approach. Front. Environ. Sci. 2021, 9, 432. [CrossRef]

3. Hou, J.; Yin, R.; Wu, W. Intensifying Forest Management in China: What does it mean, why, and how? For. Policy Econ. 2019, 98, 82-89. [CrossRef]

4. Banaś, J.; Utnik-Banaś, K.; Zięba, S.; Janeczko, K. Assessing the Technical Efficiency of Timber Production during the Transition from a Production-Oriented Management Model to a Multifunctional One: A Case from Poland 1990-2019. Forests 2021, $12,1287$. [CrossRef]

5. Bager, S.L.; Persson, U.M.; dos Reis, T.N.P. Eighty-six EU policy options for reducing imported deforestation. One Earth 2021, 4, 289-306. [CrossRef]

6. Teece, D.J.; Pisano, G.; Shuen, A. Dynamic capabilities and strategic management. Knowl. Strateg. 2009, 18, 77-116. [CrossRef]

7. Teece, D.; Peteraf, M.; Leih, S. Dynamic Capabilities and Organizational Agility: Risk, Uncertainty, and Strategy in the Innovation Economy. Calif. Manag. Rev. 2016, 58, 13-35. [CrossRef]

8. Vauhkonen, J. Predicting the provisioning potential of forest ecosystem services using airborne laser scanning data and forest resource maps. For. Ecosyst. 2018, 5, 24. [CrossRef]

9. Lindenmayer, D. Interactions between Forest Resource Management and Landscape Structure. Curr. Landsc. Ecol. Rep. 2016, 1, 10-18. [CrossRef]

10. Senganimalunje, T.C.; Chirwa, P.W.; Babalola, F.D.; Graham, M.A. Does participatory forest management program lead to efficient forest resource use and improved rural livelihoods? Experiences from Mua-Livulezi Forest Reserve, Malawi. Agrofor. Syst. 2016, 90, 691-710. [CrossRef]

11. Boukherroub, T.; LeBel, L.; Ruiz, A. A framework for sustainable forest resource allocation: A Canadian case study. Omega 2017, 66, 224-235. [CrossRef]

12. Buongiorno, J.; Gilless, J.K. Decision Methods for Forest Resource Management; Academic Press: San Diego, CA, USA, 2003; ISBN 9780121413606. 
13. Näyhä, A. Finnish forest-based companies in transition to the circular bioeconomy-drivers, organizational resources and innovations. For. Policy Econ. 2020, 110, 101936. [CrossRef]

14. Nurrochmat, D.R.; Pribadi, R.; Siregar, H.; Justianto, A.; Park, M.S. Transformation of Agro-Forest Management Policy under the Dynamic Circumstances of a Two-Decade Regional Autonomy in Indonesia. Forests 2021, 12, 419. [CrossRef]

15. Eggers, J.; Lämås, T.; Lind, T.; Öhman, K. Factors Influencing the Choice of Management Strategy among Small-Scale Private Forest Owners in Sweden. Forests 2014, 5, 1695-1716. [CrossRef]

16. Neykov, N.; Krišt'áková, S.; Hajdúchová, I.; Sedliačiková, M.; Antov, P.; Giertliová, B. Economic Efficiency of Forest EnterprisesEmpirical Study Based on Data Envelopment Analysis. Forests 2021, 12, 462. [CrossRef]

17. Gane, M. Forest Strategy: Strategic Management and Sustainable Development for the Forest Sector; Springer: Dordrecht, The Netherlands, 2007; ISBN 9781402059643.

18. Barney, J. Firm resources and sustained competitive advantage. Int. Bus. Strateg. Theory Pract. 2015, 17, $283-301$.

19. Barney, J.B.; Arikan, A.M. The Resource-based View. In The Blackwell Handbook of Strategic Management; Blackwell Publishing Ltd.: Oxford, UK, 2017; pp. 123-182.

20. Wernerfelt, B. A resource-based view of the firm. Strateg. Manag. J. 1984, 5, 171-180. [CrossRef]

21. Amit, R.; Schoemaker, P.J.H. Strategic assets and organizational rent. Strateg. Manag. J. 1993, 14, 33-46. [CrossRef]

22. Burvill, S.M.; Jones-Evans, D.; Rowlands, H. Reconceptualising the principles of Penrose's (1959) theory and the resource based view of the firm: The generation of a new conceptual framework. J. Small Bus. Enterp. Dev. 2018, 25, 930-959. [CrossRef]

23. Chatzoglou, P.; Chatzoudes, D.; Sarigiannidis, L.; Theriou, G. The role of firm-specific factors in the strategy-performance relationship: Revisiting the resource-based view of the firm and the VRIO framework. Manag. Res. Rev. 2018, 41, 46-73. [CrossRef]

24. Augier, M.; Teece, D.J. Dynamic capabilities and the role of managers in business strategy and economic performance. Organ. Sci. 2009, 20, 410-421. [CrossRef]

25. Eisenhardt, K.M.; Martin, J.A. Dynamic capabilities: What are they? Strateg. Manag. J. 2000, 21, 1105-1121. [CrossRef]

26. Helfat, C.E.; Finkelstein, S.; Mitchell, W.; Peteraf, M.; Singh, H.; Teece, D.J.; Winter, S.G. Dynamic Capabilities: Understanding Strategic Change in Organizations, 1st ed.; Wiley-Blackwell: Hoboken, NJ, USA, 2007; ISBN 978-1-4051-3575-7.

27. Teece, D.J. Explicating dynamic capabilities: The nature and microfoundations of (sustainable) enterprise performance. Strateg. Manag. J. 2007, 28, 1319-1350. [CrossRef]

28. Teece, D.J.; Pisano, G.; Shuen, A. Dynamic capabilities and strategic management. Strateg. Manag. J. 1997, 18, 509-533. [CrossRef]

29. Cyfert, S.; Roszyk-Kowalska, G.; Glabiszewski, W.; Zastempowski, M. Dynamie capabilities in the implementation of the strategy of the State Forests National Forest Holding. Sylwan 2020, 164, 795-804. [CrossRef]

30. Hansen, E.; Korhonen, S.; Rametsteiner, E.; Shook, S. Current state-of-knowledge: Innovation research in the global forest sector. J. For. Prod. Bus. Res. 2006, 3, 1-27.

31. Kożuch, A.; Marzęda, A. The effects of natural and economic factors on the financial performance of forest management units: The example of forest districts of the state forests national forest holding from eastern poland. Forests 2021, 12, 1559. [CrossRef]

32. Näyhä, A. Transition in the Finnish forest-based sector: Company perspectives on the bioeconomy, circular economy and sustainability. J. Clean. Prod. 2019, 209, 1294-1306. [CrossRef]

33. Näyhä, A.; Pesonen, H.L. Strategic change in the forest industry towards the biorefining business. Technol. Forecast. Soc. Change 2014, 81, 259-271. [CrossRef]

34. Senko, S.; Pykäläinen, J. Exploring the views of forest industry companies on the long-term forestry development in Russia: A case study in Republic of Karelia. For. Policy Econ. 2020, 120, 102311. [CrossRef]

35. Hansen, E. Responding to the bioeconomy: Business model innovation in the forest sector. Environ. Footprints Eco-Des. Prod. Process. 2016, 227-248. [CrossRef]

36. Ambrosini, V.; Bowman, C. What are dynamic capabilities and are they a useful construct in strategic management? Int. J. Manag. Rev. 2009, 11, 29-49. [CrossRef]

37. Winter, S.G. Understanding Dynamic Capabilities. Strateg. Manag. J. 2003, 24, 991. [CrossRef]

38. Zahra, S.A.; Sapienza, H.J.; Davidsson, P. Entrepreneurship and Dynamic Capabilities: A Review, Model and Research Agenda. J. Manag. Stud. 2006, 43, 917-955. [CrossRef]

39. Suddaby, R.; Coraiola, D.; Harvey, C.; Foster, W. History and the micro-foundations of dynamic capabilities. Strateg. Manag. J. 2020, 41, 530-556. [CrossRef]

40. Salvato, C.; Vassolo, R. The sources of dynamism in dynamic capabilities. Strateg. Manag. J. 2018, 39, 1728-1752. [CrossRef]

41. Kurtmollaiev, S. Dynamic Capabilities and Where to Find Them. J. Manag. Inq. 2017, 29, 3-16. [CrossRef]

42. Jantunen, A.; Tarkiainen, A.; Chari, S.; Oghazi, P. Dynamic capabilities, operational changes, and performance outcomes in the media industry. J. Bus. Res. 2018, 89, 251-257. [CrossRef]

43. GUS. Rocznik Statystyczny Leśnictwa; Główny Urząd Statystyczny: Warszawa, Polska, 2021.

44. Szramka, H.; Adamowicz, K. Kierunki modyfikacji statusu Lasów Państwowych w Polsce. Sylwan 2017, 161, 355-364.

45. Społeczna Odpowiedzialność Lasów Państwowych; Lasy Państwowe: Warszawa, Polska, 2020.

46. Strategia Państwowego Gospodarstwa Leśnego Lasy Państwowe; Lasy Państwowe: Warszawa, Polska, 2013.

47. Hair, J.F.; Black, W.C.; Babin, B.J.; Andersom, R.E. Multivariate Data Analysis: International Version; Pearson: Hoboken, NJ, USA, 2010; ISBN 1-292-02190-X. 
48. Dodge, Y. The Concise Encyclopedia of Statistics; Springer: Berlin/Heidelberg, Germany, 2010.

49. Snedecor, G.W.; Cochran, W.G. Statistical Methods, 8th ed.; Iowa State University Press: Ames, IA, USA, 1989.

50. Winkelmann, R.; Boes, S. Analysis of Microdata; Springer: Berlin/Heidelberg, Germany; New York, NY, USA, 2006.

51. Cemetic, J.; Jerman, S.; Stefan, J. A Soft Change-Management Approach Applied to Information Systems Development. Evol. Challenges Syst. Dev. 1999, 1, 719-726. [CrossRef]

52. Barney, J.B.; Wright, P.M. On becoming a strategic partner: The role of human resources in gaining competitive advantage. Hum. Resour. Manag. 1998, 37, 31-46. [CrossRef]

53. Mortazavi, S.H.; Bahrami, M. Integrated Approach to Entrepreneurship-Knowledge based Economy: A Conceptual Model. Procedia-Soc. Behav. Sci. 2012, 41, 281-287. [CrossRef]

54. Du chatenier, E.; Verstegen, J.A.A.M.; Biemans, H.J.A.; Mulder, M.; Omta, O.S.W.F. Identification of competencies for professionals in open innovation teams. RED Manag. 2010, 40, 271-280. [CrossRef]

55. Weiss, G.; Pettenella, D.; Ollonqvist, P.; Slee, B. Innovation in Forestry: Territorial and Value Chain Approaches; Cabi: Wallingford, UK, 2011; ISBN 9781845936891.

56. Hansen, E.; Nybakk, E.; Panwar, R. Innovation Insights from North American Forest Sector Research: A Literature Review. Forests 2014, 5, 1341-1355. [CrossRef] 